\title{
Effects of Plasma Treatment on Mechanical Properties of Jute Fibers and Their Composites with Polypropylene
}

\author{
Yang Il Huh, Mensah Bismark*, Sungjin Kim*, \\ Hong Ki Lee**, and Changwoon $\mathrm{Nah}^{*}{ }^{\dagger}$ \\ Department of Polymer and Fiber System Engineering, Chonnam National University, Kwangju \\ 500-757, Republic of Korea \\ *Department of Polymer Nano Science \& Technology, Jeonbuk National University, jeonju \\ 561-756, Republic of Korea \\ **Fuel Cell Regional Innovation Center, Woosuk University, Chonbuk 565-701, Republic of Korea \\ (Received August 21, 2012, Revised September 7, 2012, Accepted September 17, 2012)

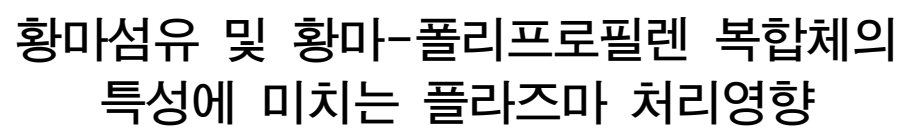 \\ 허양일·멘사비스마르크 ${ }^{*} \cdot$ 김성진 ${ }^{*} \cdot$ 이홍기 ${ }^{* \star} \cdot$ 나창운 ${ }^{* \dagger}$ \\ 전남대학교 고분자섬유시스템공학과, "전북대학교 고분자.나노공학과,${ }^{* *}$ 우석대학교 지역혁신센터 \\ 접수일(2012년 8월 21일), 수정일(2012년 9월 7일), 게재확정일(2012년 9월 17일)
}

\begin{abstract}
A jute fiber surface was modified with argon gas in a cylinder type RF plasma generator to enhance the interfacial bond strength and to optimize the plasma treatment condition. The plasma power, gas pressure, and treat time were varied to figure out any effect of those parameters on the morphology and mechanical strength of jute fibers, and the interfacial bond strength for a model composite with polypropylene resin. As the severity of plasma treatment was increased, the surface of jute fibers became rougher. Gas pressure was less effective in roughening of the surface compared with those of treat time and plasma power. Approximately $25 \%$ drop in tensile strength of jute fibers was observed for the parameters of treat time and plasma power, while little deterioration was found for gas pressure, with increasing the severity. Based on the interfacial shear strength (IFSS), the optimum plasma treatment condition was determined to be treat time of $30 \mathrm{~s}$, plasma power of $40 \mathrm{~W}$, and gas pressure of 30 mTorr.

요 약 : 계면접착력 향상을 위해 실린더형 RF 플라즈마 발생기를 이용하여 Jute fiber의 표면을 아르곤가스로 처리하였 고 최적 처리조건을 설정하였다. 플라즈마 강도, 가스압력, 및 처리시간을 변경한 후 이러한 인자들이 황마섬유 표면모 폴로지, 섬유 인장강도, 및 폴리프로필렌과의 모델복합체에서 계면접착강도에 미치는 영향을 조사하였다. 플라즈마 처리인자에 따라 황마섬유의 표면은 거칠어졌다. 가스압력의 영향은 처리시간 및 플라즈마 강도의 영향보다 다소 낮게 나타났다. 플라즈마 강도와 시간에 따라 황마섬유의 강도는 약 $25 \%$ 감소한 반면, 가스압력의 영향은 크게 나타나 지 않았다. 계면전단강도 (IFSS)를 기준으로 결정된 최적 플라즈마 처리조건은 처리시간 $30 \mathrm{~s}$, 전력 $40 \mathrm{~W}$, 가스압력 30 mTorr로 나타났다.
\end{abstract}

Keywords : plasma, jute fiber, polypropylene, composite, interfacial strength

\section{I . Introduction}

With the increasing demands for echo-friendly materials and bio-degradability in nature, various attempts have been made in polymer composites of replacing the synthesized fibers from petroleum oils with natural fibers like cellulose, wood, jute, kenaf, and hemp, etc. ${ }^{1}$ Even though the carbon and glass fibers

\footnotetext{
${ }^{\dagger}$ Corresponding Author. E-mail: cnah@jbnu.ac.kr
}

have been successfully and widely used as reinforcing materials in polymer composites, they have drawbacks of high cost and more fragile nature causing brittle catastrophic failures compared with those of natural fibers. Since the natural fibers are lower density materials, they can give considerably lightweight composites with highly specific properties such as electrical resistance, fracture toughness, heat resistance and soundproof. ${ }^{2,3}$ They also offer significant cost advantages and benefits associated with their processing compared to synthetic fibers. 
One of the major drawbacks of natural fibers-reinforced polymer composites is their poor interfacial strength between fibers and base polymers because of great difference in hydrophilic nature. For instance, natural fibers are hydrophilic, while polymers resins are hydrophobic. ${ }^{4}$ Thus, the surface modification of natural fibers is one of efficient ways to improve the bulk properties of the resulting polymer composites, since the interfacial adhesive strength plays a crucial role in the mechanical performance. Various modification methods have been suggested. ${ }^{5-7}$ They include electrochemical vapor deposition, ${ }^{8)}$ solution method, ${ }^{9,10}$ monomer or oligomer chemicals, ${ }^{11,12}$ plasma etching ${ }^{13-18}$ and plasma polymerization coating method. $^{19-25}$ When the surface of natural fibers are modified by chemical methods, the interfacial properties can be efficiently improved, but the process needs somewhat complex steps of treatments including removal and recycling of the chemicals leading to additional process cost.

Plasma etching and plasma polymerization coating techniques have been suggested as one of the most efficient and clean techniques to resolve the interfacial problems for reinforcing fillers including hydrophilic particles such as silica ${ }^{26}$ and natural fibers like jute fibers. It has been reported that the plasma treatment is efficient in modification of the hydrophilic nature of natural fibers to the hydrophobic nature, which is similar to that of polymer resins. ${ }^{27,28}$ Relatively, little literature is available for the surface modification of jute fibers with plasma.

In this study, the plasma etching technique is selected to modify the surface of jute fibers and to give rise to the improvement of interfacial adhesion between jute fibers and poly- propylene (PP) resin. The surface characteristics is investigated with Fourier-transform infrared (FT-IR) spectroscopy, scanning electron microscopy (SEM). The tensile strength of jute fibers is measured depending on various conditions of plasma treatments to figure out any deterioration due to the plasma etching. A droplet test is carried out for measuring the interfacial shear strength (IFSS) to optimize the plasma treatment parameters of treatment time, plasma power, and gas pressure.

\section{Experimental}

Natural jute fibers are supplied from Bangladesh and polypropylene (PP, J-170 grade, density of $0.9 \mathrm{~g} / \mathrm{cm}^{3}$, melt flow index of $28.0 \mathrm{~g} / 10 \mathrm{~min}$, Homan Petrochemical Co. Korea). Ar gas was used as a carrier gas.

The plasma etching was carried out with a cylinder type RF plasma generator (HPPS-300, Hanatek Co. Korea). Figure 1 shows the schematic and real photograph of the plasma machine system which is composed of a tubular type reactor, blade type stirrer, manual impedance matching system and a mass flow controller. Initially the chamber is cleaned by wiping the chamber with an acetone to avoid possible contamination. Jute fibers with the length of more than $6 \mathrm{~cm}$ are selected and they are charged in the reactor chamber, and a vacuum is then applied in the chamber. To find out the optimum condition of main parameters for the plasma treatment, treatment time, electrical power, and gas pressure are varied: 30 $\sim 120 \mathrm{~s}, 40 \sim 100 \mathrm{~W}, 30 \sim 90$ mTorr, respectively.

The surface morphology of untreated and treated jute fibers is investigated with scanning electron microscopy (SEM,
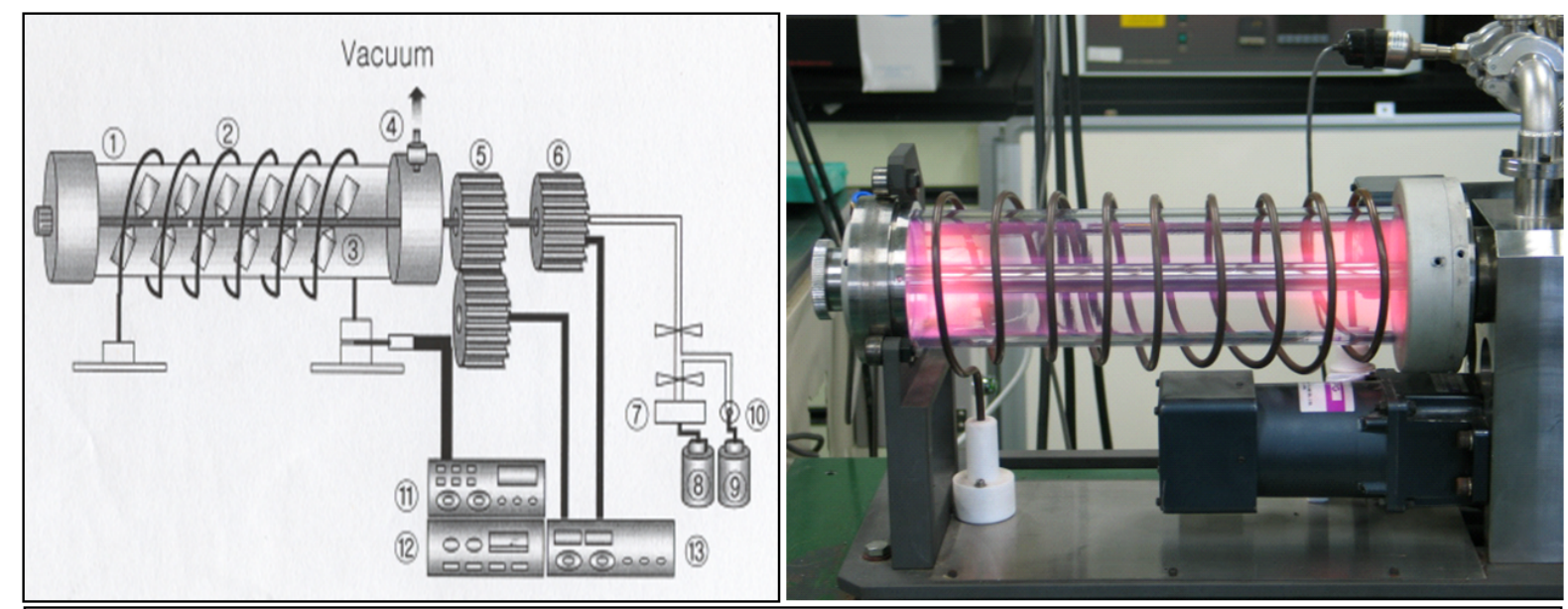

(1) Tubular reactor, (2) RF coil, (3) Blade rod, (4) Filter, (5) Gear attached to tubular reactor, (6) Gear attached to blade rod, (7) Mass flow controller, (8) Gas controller, (9) Bubbler, (10) Needle valve, (11) Impedance, matching unit, (12) RF power supply unit, (13) Tubular reactor controller

Figure 1. Schematic diagram and real photo of a RF cylinder type plasma reactor. 
JEOL JSM 5900, Japan). The chemical change in the surface is analyzed with Fourier-transform infrared (FT-IR, Shimadzu8101, Japan) spectroscopy. To figure out any effect of plasma treatment on the degradation of mechanical strength of fibers, tensile strength is monitored for untreated and treated jute fibers using a universal tensile tester (LRX Plus, Lloyd Instrument). To measure the interfacial shear strength (IFSS), a single fiber is embedded in the vertical center line of a droplet shape of molten PP resin and it is cooled to room temperature to make a composite. The single fiber is then pulled off in the tensile tester for measuring the maximum force to adhesive failure. The force is then reported as stress after dividing by cross-sectional area of fibers, together with modulus and elongation at break. Jute fibers of diameters ranging between 30 40 $\mu \mathrm{m}$ are selectively chosen for a better accuracy. The reported values are averaged one for 5 measurements for each specimen.

\section{Results and Discussion}

\section{Effect of Plasma Conditions on Properties of Jute Fibers}

To figure out any changes in chemical structure of surfaces of jutes fibers after plasma treatment, the surface of jute fibers under two treatment conditions (Condition I: Treat Time $=120$ $\mathrm{s}$, Plasma Power $=60 \mathrm{~W}$, Gas Pressure $=50 \mathrm{mTorr}$, Condition II: Treat Time $=30 \mathrm{~s}$, Plasma Power $=100 \mathrm{~W}$, Gas Pressure $=$ 50 mTorr) was analyzed using FT-IR. The FT-IR spectrums are represented in Figure 2. The stretching vibration of the $\mathrm{O}-\mathrm{H}$ bond was observed at the ranges from 3,000 to 3,500 $\mathrm{cm}^{-1}$. This is typical for jute fibers since the surfaces are composed of hydroxyl functions leading hydrophilic nature of them. After plasma treatments these peaks became more pronounced. A possible reason for this is that the surface area is increased after strong etching effects by plasma treatment. The peaks observed at $2,893 \mathrm{~cm}^{-1}$ for $\mathrm{C}-\mathrm{H}$ stretching, at $1,300-1,700 \mathrm{~cm}^{-1}$ for $\mathrm{CH}_{2}$ bending, and at $1,000-1,100 \mathrm{~cm}^{-1}$ for $\mathrm{C}-\mathrm{O}$ stretching and vibration were not much changed in terms

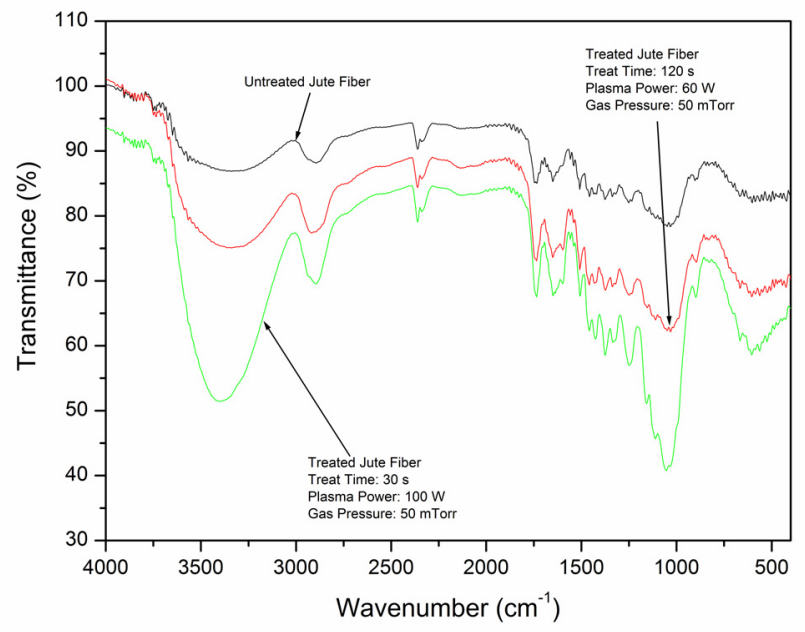

Figure 2. FT-IR spectra of untreated and treated jute fibers.
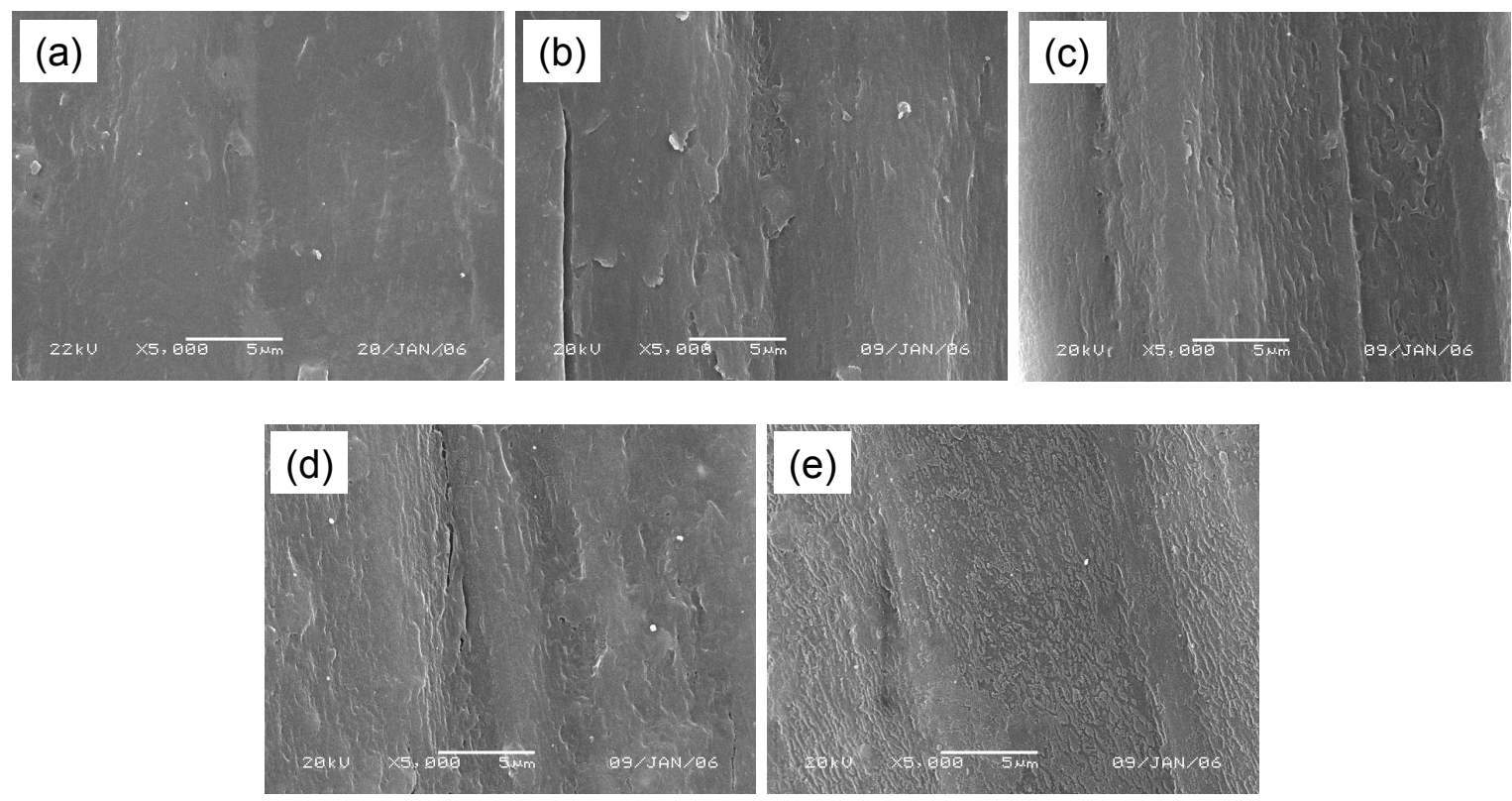

Figure 3. SEM micrographs of the surface of untreated- and plasma-treated jute fibers with variable treat times: (a) untreated, (b) $30 \mathrm{~s}$, (c) $60 \mathrm{~s}$, (d) $90 \mathrm{~s}$, and (e) $120 \mathrm{~s}$. The plasma power and gas pressure are set to $50 \mathrm{~W}$ and $60 \mathrm{mTorr}$, respectively. 

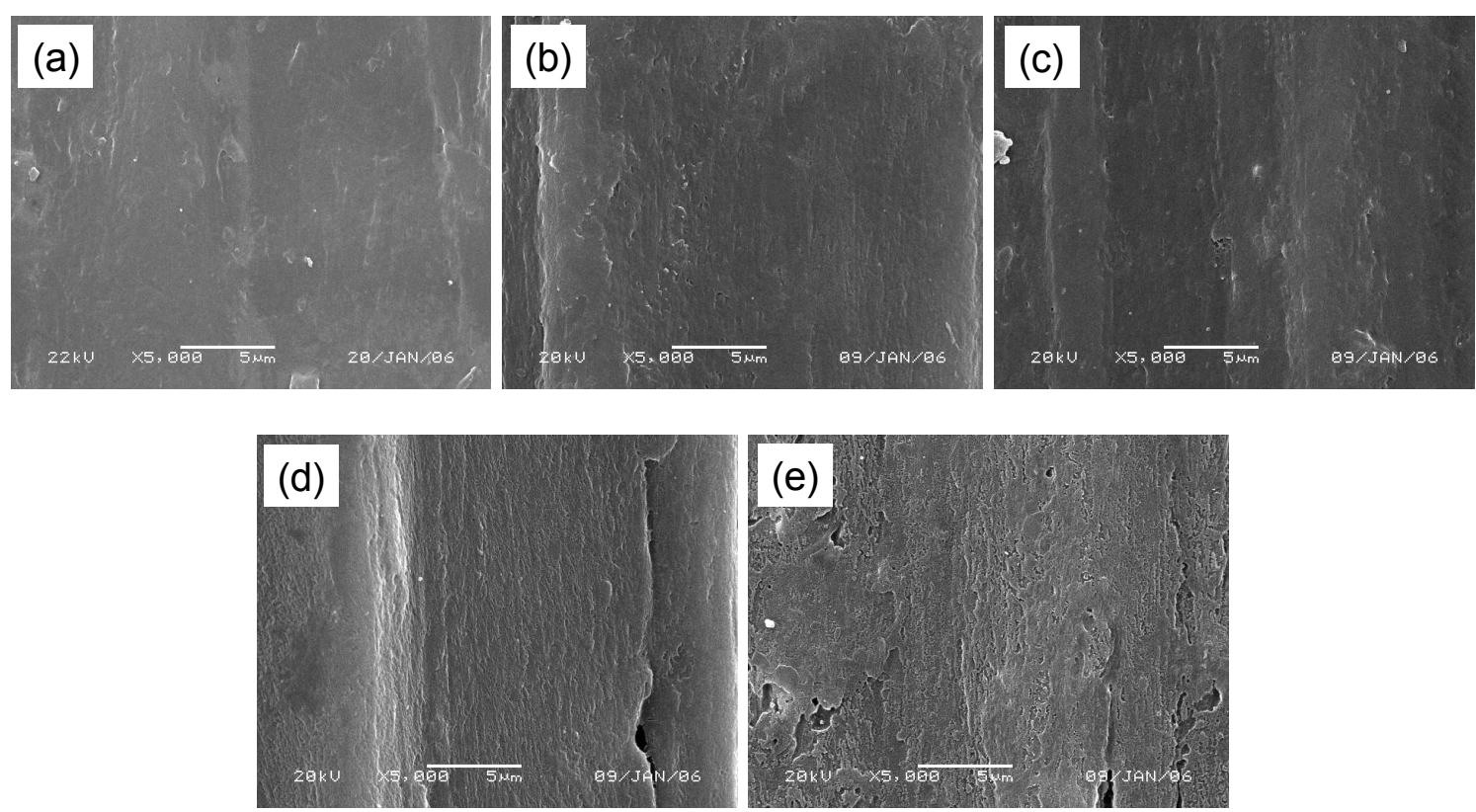

Figure 4. SEM micrographs of the surface of untreated- and plasma-treated jute fibers with variable plasma powers: (a) untreated, (b) $40 \mathrm{~W}$, (c) $60 \mathrm{~W}$, (d) $80 \mathrm{~W}$, and (e) $100 \mathrm{~W}$. The treat time and gas pressure are set to $30 \mathrm{~s}$ and $60 \mathrm{mTorr}$, respectively.
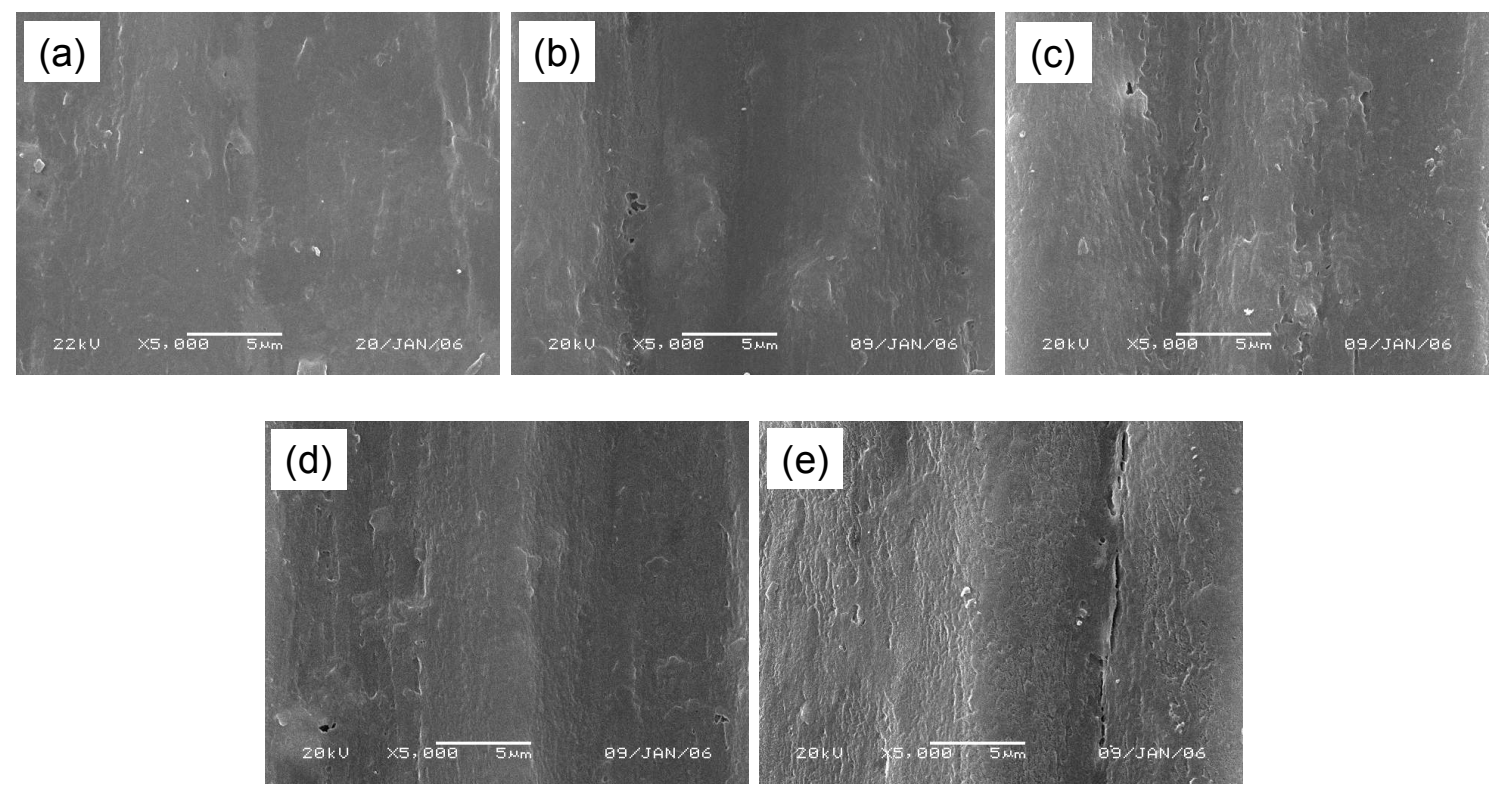

Figure 5. SEM micrographs of the surface of untreated- and plasma-treated jute fibers with variable gas pressure: (a) untreated, (b) 30 mTorr, (c) 50 mTorr, (d) 70 mTorr, and (e) 90 mTorr. The treat time and plasma power are set to $30 \mathrm{~s}$ and 40W.

of either intensity or peak position. This strongly indicates that the plasma treatment in Ar atmosphere does not change the chemical structure of jute fibers.

Figures 3-5 show the morphology change of jute fibers after plasma treatments of treat time, plasma power, and gas pressure, respectively. Initially the surface of jute fiber was smooth, and it became rougher and rougher as with increasing the plasma treatment parameters. Relatively smaller effect was observed for the gas pressure parameter, compared with other two parameters of treat time and plasma power. The observed roughening behavior is clearly seen for a single jute fiber surface (Figure 6). The roughening is expected to affect positively 

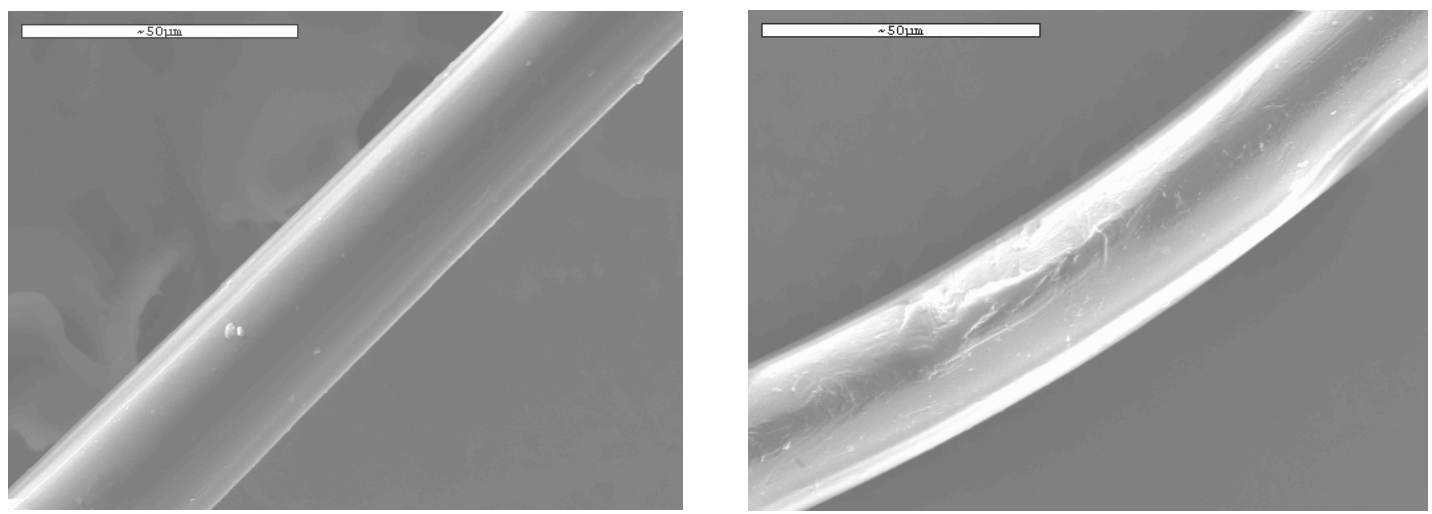

Figure 6. SEM micrographs of pristine (left) and plasma-treated jute fiber under the condition: plasma power of $100 \mathrm{~W}$, treat time of $30 \mathrm{~s}$, and gas pressure of $60 \mathrm{mTorr}$, respectively.

Table 1. Changes in Tensile Properties of Jute Fibers Depending on Various Conditions of Plasma Treatments

\begin{tabular}{|c|c|c|c|c|c|c|}
\hline \multicolumn{3}{|c|}{ Plasma Treatment Condition } & \multirow{2}{*}{$\begin{array}{l}\text { Fiber Diameter } \\
\qquad(\mu \mathrm{m})\end{array}$} & \multicolumn{3}{|c|}{ Tensile Properties } \\
\hline Treat Time(s) & Plasma Power(W) & $\begin{array}{c}\text { Gas Pressure } \\
\text { (mTorr) }\end{array}$ & & $\begin{array}{c}\text { Tensile Strength } \\
(\mathrm{GPa})\end{array}$ & Modulus (GPa) & $\begin{array}{c}\text { Elongation at } \\
\text { break }(\%)\end{array}$ \\
\hline 0 & \multirow{5}{*}{60} & \multirow{5}{*}{50} & $25.7 \pm 4.3$ & $1.37 \pm 0.153$ & $89.4 \pm 14.7$ & $1.5 \pm 0.4$ \\
\hline 30 & & & $36.0 \pm 8.8$ & $1.27 \pm 0.237$ & $92.4 \pm 33.64$ & $1.5 \pm 0.4$ \\
\hline 60 & & & $39.9 \pm 8.1$ & $1.30 \pm 0.200$ & $100.0 \pm 48.8$ & $1.5 \pm 0.3$ \\
\hline 90 & & & $35.2 \pm 4.5$ & $1.01 \pm 0.137$ & $92.9 \pm 29.6$ & $1.2 \pm 0.4$ \\
\hline 120 & & & $37.4 \pm 4.4$ & $1.01 \pm 0.110$ & $76.4 \pm 20.3$ & $1.5 \pm 0.3$ \\
\hline \multirow{5}{*}{30} & 0 & \multirow{5}{*}{50} & $25.7 \pm 43$ & $1.37 \pm 0.153$ & $89.4 \pm 14.7$ & $1.5 \pm 0.4$ \\
\hline & 40 & & $32.8 \pm 5.4$ & $1.25 \pm 0.110$ & $83.0 \pm 29.4$ & $1.6 \pm 0.4$ \\
\hline & 60 & & $36.0 \pm 8.8$ & $1.27 \pm 0.237$ & $92.4 \pm 34.3$ & $1.5 \pm 0.4$ \\
\hline & 80 & & $34.5 \pm 6.1$ & $1.06 \pm 0.153$ & $91.8 \pm 32.7$ & $1.3 \pm 0.4$ \\
\hline & 100 & & $36.7 \pm 6.0$ & $1.01 \pm 0.117$ & $69.2 \pm 14.0$ & $1.6 \pm 0.5$ \\
\hline \multirow{5}{*}{30} & \multirow{5}{*}{40} & 0 & $25.7 \pm 4.3$ & $1.37 \pm 0.153$ & $89.4 \pm 14.7$ & $1.5 \pm 0.4$ \\
\hline & & 30 & $34.4 \pm 9.7$ & $1.43 \pm 0.187$ & $97.2 \pm 44.3$ & $1.3 \pm 0.3$ \\
\hline & & 50 & $31.1 \pm 7.1$ & $1.50 \pm 0.143$ & $105.0 \pm 36.7$ & $1.2 \pm 0.3$ \\
\hline & & 70 & $34.7 \pm 7.0$ & $1.39 \pm 0.117$ & $100.0 \pm 48.4$ & $1.4 \pm 0.4$ \\
\hline & & 90 & $35.0 \pm 7.0$ & $1.42 \pm 0.157$ & $103.5 \pm 54.9$ & $1.2 \pm 0.3$ \\
\hline
\end{tabular}

to the interfacial bonding strength because of increased physical interlocking. However, it adversely affects the strength of fibers themselves.

Table 1 shows the mechanical properties of jute fibers with and without plasma treatment along with the diameter. Generally, the fiber diameter increased slightly after plasma treatment. The ultimate strength such as tensile strength and elongation at break decreased for severer plasma treatment condition. To distinguish such effect in more detail, the changes in tensile strength are plotted as a function of severity of plasma treatments (Figure 7). It clearly shows the severer deterioration effect (approximately 25\% reduction) for two parame- ters (plasma power and treat time) compared with that of gas pressure. This indicates that the plasma power plays a greater role in etching effect than gas pressure. In the case of gas pressure experiment, the plasma power is set to $40 \mathrm{~W}$, which is the lowest case. In the treat time experiment, it was set to somewhat higher level of $60 \mathrm{~W}$. Thus, the treat time may give more strong etching effect than that of gas pressure.

\section{Optimization of Plasma Conditions based on Interfacial Shear Strength}

As discussed earlier, the plasma treatment conditions play 


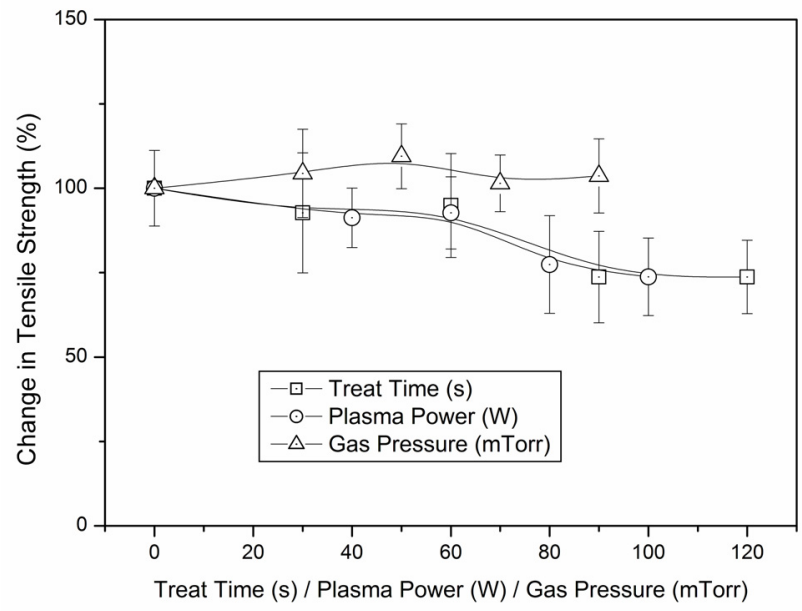

Figure 7. Changes in tensile strength with changing three parameters of treat time (s), plasma power (W) and gas pressure (mTorr).

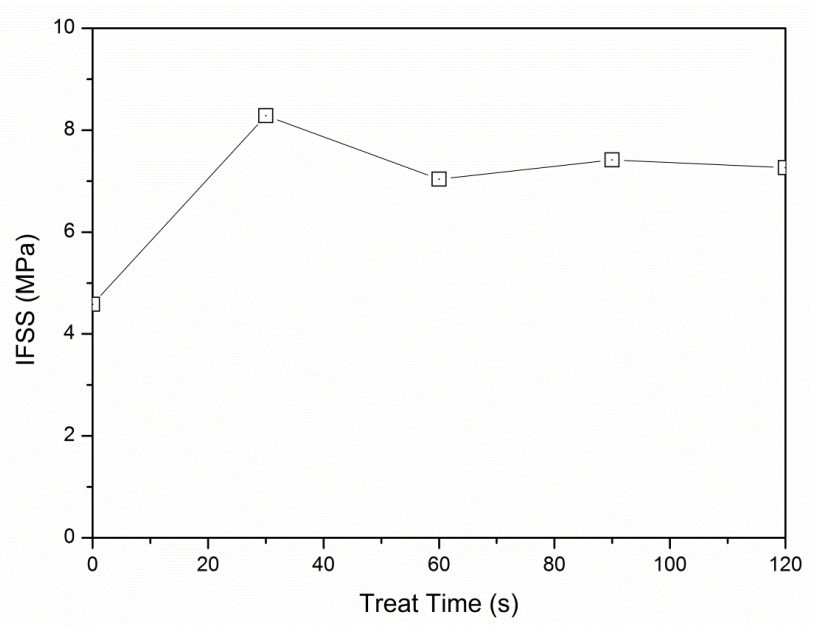

Figure 8. Interfacial shear strength (IFSS) with treat time for jute fiber/PP composites.

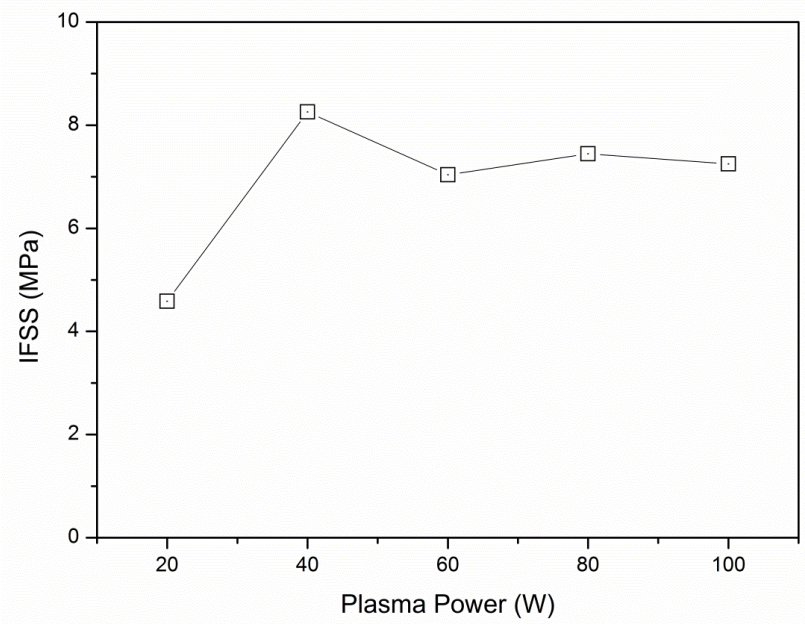

Figure 9. Interfacial shear strength (IFSS) with plasma power for jute fiber/PP composites.

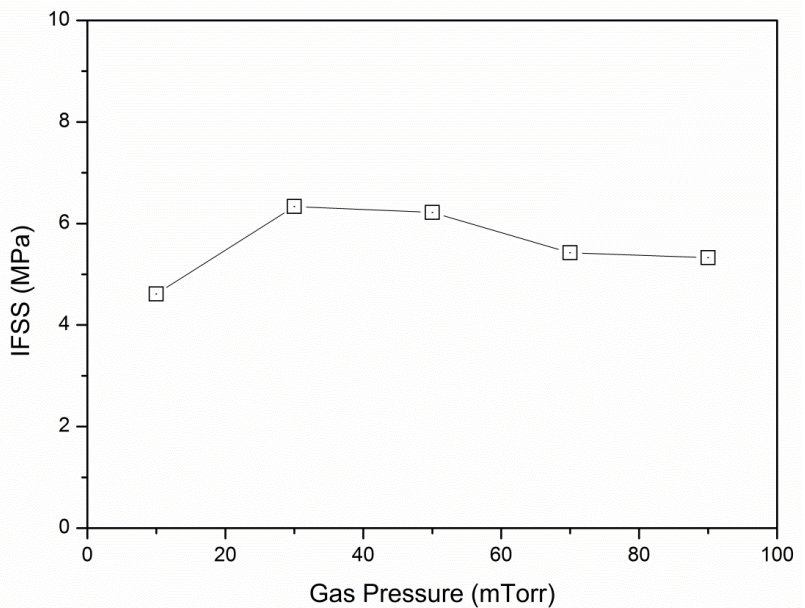

Figure 10. Interfacial shear strength (IFSS) with gas pressure for jute fiber/PP composites.

a critical role in the deterioration of jute fibers. When the jute fibers are embedded into polymer resin to make a composite, the interfacial bond strength will be a crucial parameter for determining the bulk mechanical properties of the composite. In order to maximize the plasma treatment effect, an optimum plasma condition needs to be clarified.

Figure 8 represents the effect of plasma treat time under the constant plasma power of $60 \mathrm{~W}$ and gas pressure of 50 mTorr. The interfacial shear strength (IFSS) increased rapidly (about two times higher) at initial stage and then it leveled off after $30 \mathrm{~s}$. Thus the optimum condition for plasma treat time was selected to be $30 \mathrm{~s}$.

At the optimum treat time of $30 \mathrm{~s}$, now the plasma was changed under the constant gas pressure of 50 mTorr, and the obtained result is given in Figure 9. The IFSS increased initially and showed a maximum value (about twice the strength of untreated jute fiber) at around $40 \mathrm{~W}$, and then slightly decreased with further increasing of power. The observed decreasing trend at extremely severe conditions might be due to the fact that fibers lost their inherent strength (about $25 \%$ drop in tensile strength in Table 1 and Figure 7) compared to their interfacial bonding strength with the PP resin. Thus, the optimum plasma power was selected to be $40 \mathrm{~W}$.

Finally the gas pressure was changed under the determined optimum condition of treat time (30 s) and plasma power (40 $\mathrm{W})$, and the IFSS result is shown in Figure 10. The IFSS slightly increased and showed a maximum ( $40 \%$ increase) and then decreased again. Compared with other parameters, the overall effect is somewhat lower. This again strongly supports the plasma power is a major parameter for both the fiber strength and interfacial bond strength. Thus, it can be concluded that the optimum condition for plasma treatment is plasma power of $40 \mathrm{~W}$, gas pressure of 30 mTorr and treat time of $30 \mathrm{~s}$. 


\section{Conclusions}

The jute fiber surface was modified using a cylinder type RF plasma generator and the strength of fibers and interfacial bond strength between fibers and polypropylene resin was investigated to establish an optimum condition of plasma parameters of treat time, plasma power, and gas pressure.

As the severity of plasma treatment was increased, the surface of jute fibers became rougher. Gas pressure was less effective in roughening of the surface compared with those of treat time and plasma power. Approximately $25 \%$ drop in tensile strength of jute fibers was observed for the parameters of treat time and plasma power, while little deterioration was found for gas pressure, with increasing the severity.

Based on the interfacial shear strength (IFSS), the optimum plasma treatment condition is treat time of $30 \mathrm{~s}$, plasma power of $40 \mathrm{~W}$, and gas pressure of $30 \mathrm{mTorr}$.

\section{Acknowledgement}

This research was carried out under the World Class University Program of the Korea Science and Engineering Foundation, funded by the Ministry of Education, Science and Technology (R33-2008-000-10016-0) and the Program of Regional Innovation Center which was conducted by the Ministry of Knowledge Economy of the Korean Government. The authors would like to thank Professor Tae-Ho Yoon at Gwangju Institute of Science and Technology for helpful discussion in plasma treatment.

\section{References}

1. A. K. Bledzki and J. Gassan, "Composites reinforced with cellulose based fibres", Prog. Polym. Sci., 24, 221 (1999).

2. R. Karnani, M. Krishnan, and R. Narayan, "Biofiber-reinforced polypropylene composites", Polym. Eng. Sci., 37, 476 (1997).

3. T. M. Gowd, A.C.B. Naidu, and R. Chhay, "Some mechanical properties of untreated jute fabric-reinforced polyester composites", Compos. Part A, 30, 277 (1999).

4. A. C. Karmaker and J. A. Youngquist, "Injection molding of polypropylene reinforced with short jute fibers", J. Appl. Polym. Sci., 62, 1147 (1996).

5. G. Krekel, U. J. Zielke, K. J. Hüttinger, and W. P. Hoffman, "The relevance of the surface structure and surface chemistry of carbon fibres in their adhesion to high temperature thermoplastics. Part III Interface adhesion and reinforcement effects", J. Mater. Sci., 29, 3984 (1994).

6. J. Harvey, C. Kozlowski, and P. M. A. Sherwood, "X-ray photoelectron spectroscopic studies of carbon fibre surfaces. Part 6 Pilot plant surface treatment and epoxy resin composites", J. Mater. Sci., 22, 1585 (1987).
7. C. A. Baillie and M. G. Bader, "Some aspects of interface adhesion of electrolytically oxidized carbon fibres in an epoxy-resin matrix", J. Mater. Sci., 29, 3822 (1994).

8. H.-T. Chiu and J.-S. Lin, "Electrochemical deposition of polypyrrole on carbon fibres for improved adhesion to the epoxy resin matrix", J. Mater. Sci., 27, 319 (1992).

9. I.-C. Kim and T.-H. Yoon, "Enhanced interfacial adhesion of carbon fibers to vinyl ester resin using poly(arylene ether phosphine oxide) coatings as adhesion promoters", J. Adhes. Sci. Technol., 14, 545 (2000).

10. H. M. Kang, T. H. Yoon, M. Bump, and J. S. Riffle, "Effect of solubility and miscibility on the adhesion behavior of polymer-coated carbon fibers with vinyl ester resins", J. Appl. Polym. Sci., 79, 1042 (2001).

11. J. J. Lesko, F. E. Swain, J. M. Cartwright, J. W. Chin, K. L. Reifsnider, D. A. Dillard, and J. P. Wightman, "Interphases Developed from Fiber Sizings and Their Chemical-Structural Relationship to Composite Compressive Performance", $J$. Adhes., 45, 43 (1994).

12. S. D. Jenkins, G. T. Emmerson, P. T. McGrail, and R. M. Robinson, "Thermoplastic Sizing of Carbon Fibres in High Temperature Polyimide Composites", J. Adhes., 45, 15 (1994).

13. E. M. Liston, "Plasma Treatment for Improved Bonding: A Review", J. Adhes., 30, 199 (1989).

14. G. J. Farrow and C. Jones, "The Effect of Low Power Nitrogen Plasma Treatment of Carbon Fibres on the Interfacial Shear Strength of Carbon Fibre/Epoxy Composites", $J$. Adhes., 45, 29 (1994).

15. G. J. Farrow and K. E. Atkinson, N. Fluck and C. Jones, "Effect of low-power air plasma treatment on the mechanical properties of carbon fibres and the interfacial shear strength of carbon fibre-epoxy composites", Surf. Interface Anal., 23, 313 (1995).

16. B. Okhuysen, R. C. Cochran, R. E. Allred, F. Sposili, and T. M. Donnellan, "Interface/Interphase Studies in Epoxy Matrix Composites", J. Adhes., 45, 3 (1994).

17. S. Mujin, H. Baorong, W. Yisheng, T. Ying, H. Weiqui, and D. Youxian, "The surface of carbon fibres continuously treated by cold plasma", Compos. Sci. Technol., 34, 353 (1989).

18. B. S. Jin, K. H. Lee, and C. R. Choe, "Properties of carbon fibers modified by oxgen plasma", Polym. Int., 34, 181 (1994).

19. G. Dagli and N.-H. Sung, "Properties of carbon/graphite fibers modified by plasma polymerization", Polym. Compos., 10, 109 (1989).

20. N. Dilsiz, E. Ebert, W. Weisweiler, and G. J. Akovali, "Effect of Plasma Polymerization on Carbon Fibers Used for Fibers/Epoxy Composites", J. Colloid Interf. Sci., 170, 241 (1995).

21. S. Feih and P. Schwartz, "Modification of the carbon fiber/matrix interface using gas plasma treatment with acetylene and oxygen", J. Adhes. Sci. Technol., 12, 523 (1998).

22. L. Y. Yuan, S. S. Shyu, and J. Y. Lai, "Plasma surface treat- 
ments of carbon fibers. Part 2: Interfacial adhesion with poly(phenylene sulfide)", Compos. Sci. Technol., 45, 9 (1992).

23. W. Weisweiler, in: NATO ASI Series, Series. E, No. 230, Interfacial Interactions in Polymeric Composites, G. Akovali (Ed.), p. 269. Kluwer Academic, Boston (1993).

24. Y. L. Zou and A. N. Netravali, "Ethylene/ ammonia plasma polymer deposition for controlled adhesion of graphite fibers to PEEK", J. Adhes. Sci. Technol., 9, 1505 (1995).

25. N. Lopattananon, A. P. Kettle, D. Tripathi, A. J. Beck, E. Duval, R. M. France, R. D. Short, and F. R. Jones, "Interface molecular engineering of carbon-fiber composites", Compos.
Part A, 30, 49 (1999).

26. G. Mathew, M.-Y. Huh, J. M. Rhee, M.-H. Lee, and C. Nah, "Improvement of properties of silica-filled styrene-butadiene rubber composites through plasma surface modification of silica", Polym. Adv. Technol., 15, 400 (2004).

27. S. G. Lee, S.-S. Choi, W. H. Park, and D. Cho, "Characterization of surface modified flax fibers and their biocomposites with PHB”, Macromol. Symp., 197, 89 (2003).

28. X. Yuan, K. Jayaraman, and D. Bhattacharyya, "Mechanical properties of plasma-treated sisal fibre-reinforced polypropylene composites", J. Adhes. Sci. Tech., 18, 1027 (2004). 